\title{
Cryptococcal infection of the colon in a patient without concurrent human immunodeficiency infection: a case report and literature review
}

\author{
Alvaro Quincho-Lopez ${ }^{1}$ - Noah Kojima ${ }^{2}$ (D) John M. Nesemann ${ }^{3} \cdot$ Rogger Verona-Rubio ${ }^{4} \cdot$ Dina Carayhua-Perez $^{5}$
}

Received: 27 August 2020 / Accepted: 3 May 2021 / Published online: 13 May 2021

(C) The Author(s) 2021

\begin{abstract}
Cryptococcosis is a fungal infection that is rarely reported in patients without human immunodeficiency virus (HIV) infection, especially when the central nervous system (CNS) or pulmonary system is not involved. We report a case of isolated colonic cryptococcosis without disseminated disease in a 64-year-old immunocompetent woman without HIV infection who presented with chronic diarrhea and no episodes of fever or weight loss. The diagnosis was based on histopathology examination. Furthermore, we performed a literature review showing that few reports have been published so far and in the case of colonic cryptococcal infection, the prognosis is favorable among HIV-uninfected patients.
\end{abstract}

Keywords Cryptococcal infection · Colon · Non-HIV

\section{Introduction}

Cryptococcus spp. are the causative agents of cryptococcosis, a fungal infection that occurs worldwide. Cryptococcosis is one of the leading causes of death among immunosuppressed individuals, especially among those infected with human immunodeficiency virus (HIV) [1]. Although Cryptococcus neoformans causes more than $90 \%$ of cryptococcal infections, Cryptococcus gattii affects a greater proportion of immunocompetent individuals, and has a high prevalence in Latin America [1, 2].

Noah Kojima

nkojima@ucla.edu

1 San Fernando Medical School, Universidad Nacional Mayor de San Marcos, Lima, Peru

2 Department of Medicine, David Geffen School of Medicine, University of California, Los Angeles, CA, USA

3 David Geffen School of Medicine, University of California, Los Angeles, CA, USA

4 Department of Pathology, Hospital Nacional Arzobispo Loayza, Lima, Peru

5 Department of Pathology, Hospital Nacional Daniel Alcides Carrion, Lima, Peru
Cryptococcus spp. can infect the central nervous system (CNS) and the pulmonary system; however, it can spread to any organ system, especially among cases of severe immunosuppression. Despite this ability to infect any organ system, colonic cryptococcosis that spares other digestive organs is rare, especially among immunocompetent persons [2].

Herein, we report a case of isolated colonic cryptococcosis without disseminated disease in an immunocompetent patient without HIV infection. Additionally, we performed a literature review of other cases of cryptococcosis that have involved the colon, either individually or as part of a disseminated disease, among non-HIV-infected patients.

\section{Case presentation}

A 64-year-old woman with a history of high-grade medullary thyroid carcinoma and untreated asthma presented to the Arzobispo Loayza Hospital in Lima, Peru with a chief complaint of 5 months of intermittent chronic diarrhea. She also reported sporadic diffuse abdominal pain that occurred 1 month ago, rectal bleeding, and a painful ano-rectal mass, without fever or weight loss.

On admission, her heart rate was 89 beats/min, respiratory rate of 15 breaths $/ \mathrm{min}$, blood pressure of $115 / 80 \mathrm{~mm} \mathrm{Hg}$, temperature of $37.6^{\circ} \mathrm{C}$, and her oxygen saturation was $98 \%$. 
On physical examination, her abdomen was symmetric, soft, and non-tender without distention. Bowel sounds were present. No masses, hepatomegaly, or splenomegaly were noted. On the left side of her thyroid, a painless mass without lymphadenopathy was noted. Laboratory results were as follows: hemoglobin: $12.5 \mathrm{~g} / \mathrm{dL}$; WBC: $6160 \mathrm{cell} / \mathrm{mm}^{3}$ with $12 \%$ eosinophils (absolute eosinophil count, 739); platelets: 317,000/ $\mathrm{mm}^{3}$; total proteins: $7.5 \mathrm{~g} / \mathrm{dL}$; albumin: $4.3 \mathrm{~g} / \mathrm{dL}$; INR: 0.9 ; basal glycemia: $97 \mathrm{mg} / \mathrm{dL}$; glycosylated hemoglobin: $5.5 \%$. ELISA HTLV-1 and ELISA HIV-1 were non-reactive. In addition to serologic testing, the HIV RNA assay was negative. Serum creatinine and liver function tests were normal. Chest radiography was negative for nodules, hilar lymphadenopathy, and pleural effusions.

A colonoscopy was performed and described segmental erosive sigmoiditis (Fig. 1a). In the sigmoid colon, $30 \mathrm{~cm}$ from the anal margin, a congestive and eroded mucosa was evident on the fold, with loss of the submucosal vascular pattern that compromises $60 \%$ of the circumference, not more than $2 \mathrm{~cm}$ in length. Grade III internal hemorrhoids were also observed.

Histopathological examination of the colonic tissue using hematoxylin and eosin (H\&E) and periodic acid-Schiff (PAS) staining (Fig. $1 \mathrm{~b}$ and $1 \mathrm{c}$, respectively) revealed superficial mucosa with moderate acute and chronic inflammatory infiltrate, presence of granulomas, with multinucleated giant cells and PAS-positive thick-walled ovoid structures, consistent with Cryptococcus spp. Serum latex agglutination test for cryptococcal antigen (CrAg) was non-reactive. Further workup such as blood culture and cerebrospinal fluid (CSF) examination through lumbar puncture was negative for fungal or bacterial infection, being the patient diagnosed as an isolated colonic cryptococcosis case without disseminated disease. She started antifungal therapy with fluconazole $400 \mathrm{mg} /$ day for 6 months with clinical improvement.

\section{Discussion}

The diagnosis of cryptococcosis is based on the direct visualization of the fungus with an India ink stain, culture of biological samples such sputum or CSF, histopathologic staining of tissues, or serological tests that detect the presence of the cryptococcal polysaccharide capsular antigen (CrAg) [1, 2]; the latex agglutination test and lateral flow assay (LFA) can be used in both serum and CSF samples [3, 4]. Our patient serological assays were non-reactive, so we chose to obtain a biopsy for histologic diagnosis.

Few cases of HIV-negative colonic cryptococcal infection have been published so far; we found 12 case reports in our literature review (Table 1). In these cases, a majority of the patients were female $(58.3 \%$; 7/12) and $66.6 \%(8 / 12)$ had a comorbidity, the most common of which was Crohn's disease $(25 \% ; 3 / 12)$, which is often treated with immunosuppression $[11,12,15]$. The other 4 patients presented without any comorbidities $[6,9,10,16]$. Diarrhea was the most frequent presenting symptom, occurring in $50 \%$ of the patients $[6$, $11-13,15,16]$, followed by abdominal pain $(41.6 \% ; 5 / 12)$ $[6,11,12,15,16]$, and fever $(33.3 \% ; 4 / 12)[8,11,12,15]$. These three symptoms occurred simultaneously in $25 \%(3 / 12)$ of the reported cases $[11,12,15]$. Only one patient was asymptomatic on presentation and was diagnosed incidentally [14]. The ascending colon was affected in $41.6 \%(5 / 12)$ of the

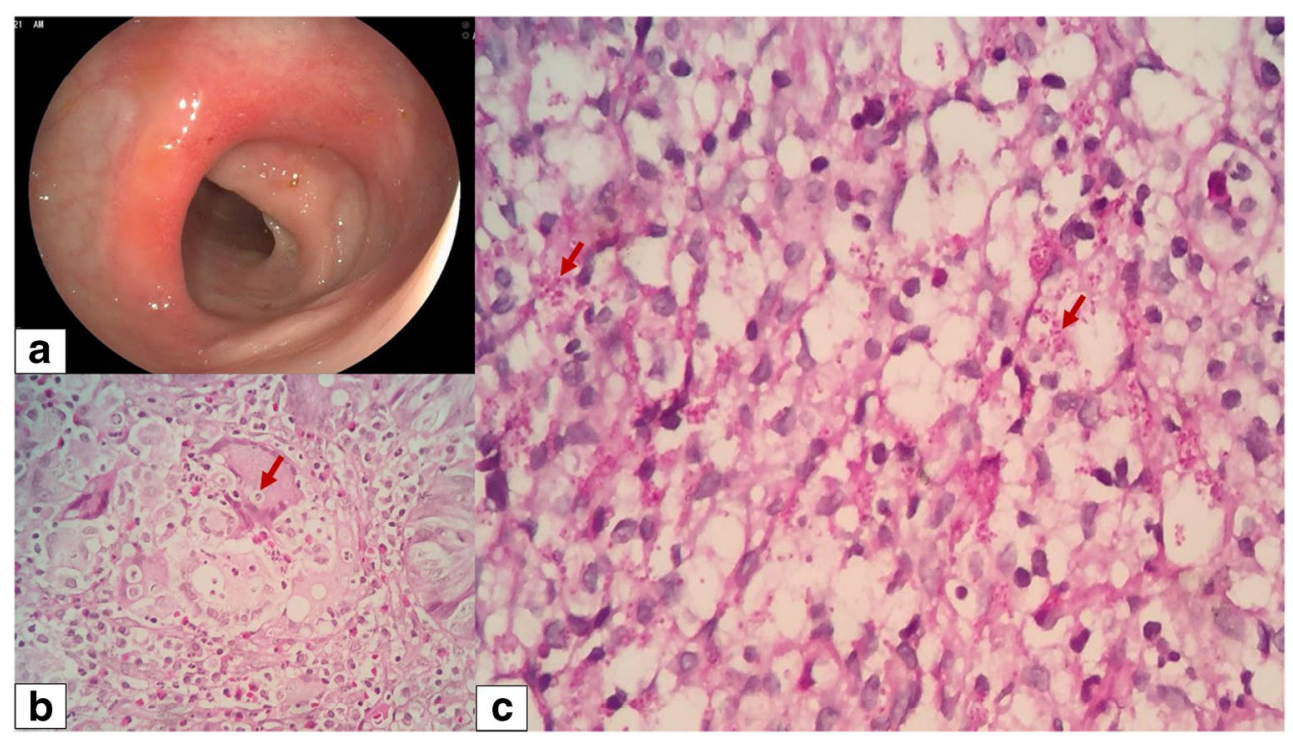

Fig. 1 a Colonoscopy: Erythematous area is observed with the presence of small diffuse erosions circumscribed by normal mucosa in the central part of the haustra in the sigmoid colon. b Hematoxylin and eosin (H\&E) stain shows a foreign body granuloma and multinucleated giant cells phagocytizing intracellular spherical structures that measure between 3 and $15 \mu \mathrm{m}$ surrounded by a capsule of variable thickness that corresponds to Cryptococcus spp. (at magnification of $\times 400$ ). $\mathbf{c}$ Periodic acid-Schiff (PAS) stain shows a conglomerate of histiocytes containing intracytoplasmic spherical structures corresponding to Cryptococcus spp. (at magnification of $\times 100$ ) 
Table 1 Colonic cryptococcal infection case reports in non-HIV patients

\begin{tabular}{|c|c|c|c|c|c|c|c|c|}
\hline Reference & $\begin{array}{l}\text { Sex/ } \\
\text { age } \\
\text { (years) }\end{array}$ & Underlying conditions & Clinical presentation & Type of lesion & $\begin{array}{l}\text { Colonic } \\
\text { distribution }\end{array}$ & $\begin{array}{l}\text { Another } \\
\text { organ } \\
\text { involvement }\end{array}$ & Treatment & Outcome \\
\hline Zelman [5] & $\mathrm{M} / 25$ & CML, chemotherapy & NR & Ulcer & $\begin{array}{l}\text { Ascending and } \\
\text { transverse } \\
\text { colon }\end{array}$ & $\begin{array}{l}\text { CNS and } \\
\text { visceral } \\
\text { infiltra- } \\
\text { tion }\end{array}$ & None & Died \\
\hline Unat [6] & $\mathrm{M} / 16$ & None & $\begin{array}{l}\text { Abdominal pain, } \\
\text { diarrhea, LGIB }\end{array}$ & Mass & $\begin{array}{l}\text { Descending } \\
\text { colon }\end{array}$ & No & $\mathrm{Sx}+\mathrm{AmB}$ & Resolved \\
\hline Hutto [7] & $\mathrm{F} / 29$ & Job's syndrome & $\begin{array}{l}\text { Chronic perirectal } \\
\text { abscess }\end{array}$ & $\begin{array}{l}\text { Stricture, } \\
\text { mass }\end{array}$ & $\begin{array}{l}\text { Ascending colon, } \\
\text { perirectal area }\end{array}$ & No & $\mathrm{Sx}+\mathrm{AmB}$ & Resolved \\
\hline Daly [8] & $\mathrm{M} / 63$ & $\begin{array}{l}\text { Cirrhosis, splenectomy, } \\
\text { corticosteroids }\end{array}$ & $\begin{array}{l}\text { Fever, chills, } \\
\text { peritonitis, skin } \\
\text { lesions }\end{array}$ & Mass & Transverse colon & $\begin{array}{l}\text { Skin and } \\
\text { omentum }\end{array}$ & $\mathrm{AmB}+5 \mathrm{FC}$ & Died \\
\hline Melato [9] & $\mathrm{F} / 84$ & None & Rectal bleeding & $\begin{array}{l}\text { Pedunculated } \\
\text { polyp }\end{array}$ & Sigmoid colon & No & Polypectomy & Resolved \\
\hline Song [10] & $\mathrm{F} / 27$ & None & Melena & Mass & Ascending colon & No & $\mathrm{AmB}+\mathrm{FCZ}$ & Resolved \\
\hline Osawa [11] & $\mathrm{M} / 53$ & $\begin{array}{l}\text { Silicosis, Crohn's disease } \\
\text { (INX, prednisone, AZA) }\end{array}$ & $\begin{array}{l}\text { Fever, abdominal } \\
\text { pain, and diarrhea }\end{array}$ & Ulcer & Cecum & $\mathrm{CNS}$ & $\mathrm{AmB}+5 \mathrm{FC}$ & Resolved \\
\hline $\begin{array}{l}\text { Sciaudone } \\
\text { [12] }\end{array}$ & $\mathrm{F} / 26$ & Crohn's disease & $\begin{array}{l}\text { Abdominal pain, } \\
\text { fever, diarrhea, } \\
\text { melena, weight } \\
\text { loss }\end{array}$ & $\begin{array}{l}\text { Ulcer, patchy } \\
\text { lesions }\end{array}$ & $\begin{array}{l}\text { Sigmoid colon, } \\
\text { transverse } \\
\text { colon, and } \\
\text { cecum }\end{array}$ & NR & FCZ & Resolved \\
\hline Cicora [13] & $\mathrm{F} / 59$ & $\begin{array}{l}\text { Hypertension, Chagas } \\
\text { disease, and kidney } \\
\text { transplant }\end{array}$ & Diarrhea & Ulcer & NS & NR & $\mathrm{AmB}+\mathrm{FCZ}$ & Resolved \\
\hline Túlio [14] & $\mathrm{M} / 70$ & $\begin{array}{l}\text { Madelung disease, } \\
\text { hypertension, diabetes, } \\
\text { adenocarcinoma } \\
\text { (pancreas) }\end{array}$ & None & $\begin{array}{l}\text { Ulcer, } \\
\text { stricture }\end{array}$ & Ascending colon & No & NR & NR \\
\hline $\begin{array}{l}\text { Chavapradit } \\
\text { [15] }\end{array}$ & $\mathrm{F} / 58$ & $\begin{array}{l}\text { Crohn's disease } \\
\text { (prednisolone, AZA, } \\
\text { MZ) }\end{array}$ & $\begin{array}{l}\text { Abdominal pain, } \\
\text { fever, and diarrhea }\end{array}$ & Ulcer, mass & $\begin{array}{l}\text { Ascending colon, } \\
\text { ileocecal valve }\end{array}$ & Lungs & $\mathrm{AmB}+\mathrm{FCZ}$ & Resolved \\
\hline $\begin{array}{l}\text { Medina } \\
\text { Alvarez } \\
{[16]}\end{array}$ & $\mathrm{F} / 57$ & None & $\begin{array}{l}\text { Abdominal pain, } \\
\text { diarrhea, } \\
\text { hematochezia }\end{array}$ & $\begin{array}{l}\text { Nodular } \\
\quad \text { lesions }\end{array}$ & $\begin{array}{l}\text { From rectum to } \\
\text { descending } \\
\text { colon }\end{array}$ & NR & $\mathrm{AmB}+\mathrm{FCZ}$ & Resolved \\
\hline
\end{tabular}

Note. $A m B$ amphotericin B; $A Z A$ azathioprine; $C M L$ chronic myeloid leukemia; $C N S$ central nervous system; $F C Z$ fluconazole; $F$ feminine; $I N X$ infliximab; $L$ lower gastrointestinal bleeding; $M$ masculine; $M Z$ mesalazine; $N R$ not reported; $N S$ not specified; $S x$ surgery; 5 - $F C$ flucytosine

cases $[5,7,10,14,15]$. The types of lesions observed during colonoscopy were ulcers $[5,11-15]$ and masses $[6-8,10,15]$, in $50 \%(6 / 12)$ and $41.6 \%(5 / 12)$ of the patients, respectively. Disseminated disease ( $>1$ noncontiguous site) was found in four $(33.3 \%$; 4/12) patients: one in skin [8], one in lungs [15], and two in the CNS $[5,11]$. Amphotericin B (AmB) plus fluconazole (FCZ) was the preferred therapy in $33.3 \%$ (4/12) of the cases $[10,13,16]$, and all cases that received this treatment improved clinically; $16 \%(2 / 12)$ of patients received AmB plus flucytosine $(5 \mathrm{FC})[8,11]$, with mixed results, as one patient died $(8.3 \% ; 1 / 12)$; the rest of the cases were managed with FCZ monotherapy $(8.3 \%$; 1/12) [9], or surgery plus $\mathrm{AmB}(16.6 \% ; 2 / 12)[6,7]$, all with favorable results. There were two $(16.6 \% ; 2 / 12)$ deaths, one from respiratory failure [5] and another from multiple organ failure [8].

In a more general review of fungal infections in the colon, $77 \%$ of cryptococcosis occurred in immunosuppressed patients (either with HIV infection or on immunosuppressive therapy), and more than half developed disseminated disease [17]. Although many of the symptoms it produces are general, the most specific is perirectal abscess [7], Cryptococcus spp. being the only fungus that invades the perirectal area [17].

According to the 2010 Infectious Diseases Society of America (IDSA) clinical practice guidelines, for nondisseminated cryptococcal disease that does not involve the CNS or lungs, $400 \mathrm{mg}$ of oral fluconazole per day for 6-12 months is recommended [18]. Although overall response to antifungal therapy is variable, all reports of patients without HIV infection or disseminated disease demonstrate favorable response to treatment [17]. This is consistent with our review of the literature, since only two patients $[5,8]$, both with disseminated disease, passed away. This suggests that regardless of the treatment received, the prognosis is generally favorable among patients without HIV infection. 
Some limitations that we must emphasize are that the patient was not further screened for primary immunodeficiencies and only some of the most common secondary immunodeficiencies (i.e., diabetes, malnutrition) were ruled out.

Clinicians should be aware that cryptococcal infection can occur among immunocompetent patients without neurologic or systemic compromise. Here we described an unusual case of a patient presenting with chronic diarrhea. Histopathological diagnosis is essential, even more so if serological methods are non-reactive, as in our case. Among HIV-uninfected patients, the diagnosis is usually late, although in the case of colonic infection, the prognosis is favorable.

Author contribution AQL, RVR, and DCP contributed to acquisition of data and permissions. AQL and JMN contributed to drafting of the manuscript. NK contributed to critical revision of the final version. All authors approved the final version of the manuscript.

Availability of data and material Data sharing is not applicable to this article as no datasets were generated or analyzed during the current study.

Code availability Not applicable.

\section{Declarations}

Ethics approval Ethics approval for this study was waived by the local ethics committee at Universidad Nacional Mayor de San Marcos because it is a single-case study.

Consent to participate Written informed consent was obtained from the patient.

Consent for publication The participant has consented to the submission of the case report to the journal.

Competing interests The authors declare no competing interests.

Open Access This article is licensed under a Creative Commons Attribution 4.0 International License, which permits use, sharing, adaptation, distribution and reproduction in any medium or format, as long as you give appropriate credit to the original author(s) and the source, provide a link to the Creative Commons licence, and indicate if changes were made. The images or other third party material in this article are included in the article's Creative Commons licence, unless indicated otherwise in a credit line to the material. If material is not included in the article's Creative Commons licence and your intended use is not permitted by statutory regulation or exceeds the permitted use, you will need to obtain permission directly from the copyright holder. To view a copy of this licence, visit http://creativecommons.org/licenses/by/4.0/.

\section{References}

1. May RC, Stone NRH, Wiesner DL, Bicanic T, Nielsen K (2016) Cryptococcus: from environmental saprophyte to global pathogen. Nat Rev Microbiol 14:106-117

2. Maziarz EK, Perfect JR (2016) Cryptococcosis. Infect Dis Clin N Am 30:179-206

3. Binnicker MJ, Jespersen DJ, Bestrom JE, Rollins LO (2012) Comparison of four assays for the detection of cryptococcal antigen. Clin Vaccine Immunol 19:1988-1990

4. Huang HR, Fan LC, Rajbanshi B, Xu JF (2015) Evaluation of a new cryptococcal antigen lateral flow immunoassay in serum, cerebrospinal fluid and urine for the diagnosis of cryptococcosis: a meta-analysis and systematic review. PLoS One 10:1-10

5. Zelman S, O’Neil R, Plaut A (1951) Disseminated visceral torulosis without nervous system involvement with clinical appearance of granulocytic leukemia. Am J Med 11:658-664

6. Unat E, Pars B, Kosyak J (1960) A case of cryptococcosis of the colon. Br Med J 2:1501-1502

7. Hutto JO, Bryan CS, Greene FL, White CJ, Gallin JI (1988) Cryptococcosis of the colon resembling Crohn's disease in a patient with the hyperimmunoglobulinemia E-recurrent infection (Job's) syndrome. Gastroenterology 94:808-812

8. Daly J, Porter K, Chong F, Robillard R (1990) Disseminated, nonmeningeal gastrointestinal cryptococcal infection in an HIVnegative patient. Am J Gastroenterol 85:1421-1424

9. Melato M, Gorji N (1998) Primary intestinal cryptococcosis mimicking adenomatous polyp in an HIV-negative patient. Am J Gastroenterol 93:1592-1593

10. Song JC, Kim SK, Kim ES, Jung IS (2008) A case of colonic cryptococcosis. Korean J Gastroenterol 52:255-260

11. Osawa R, Singh N (2010) Colitis as a manifestation of infliximabassociated disseminated cryptococcosis. Int J Infect Dis 14:e436e440

12. Sciaudone G, Pellino G, Guadagni I, Somma A, D'Armiento FP, Selvaggi F (2011) Disseminated Cryptococcus neoformans infection and Crohn's disease in an immunocompetent patient. J Crohn's Colitis 5:60-63

13. Cicora F, Petroni J, Roberti J (2015) Cryptococcosis presenting as a colonic ulcer in a kidney transplant recipient: a case report. Transplant Proc 47:2786-2787

14. Túlio MA, Figueiredo P, Cassis J (2017) Rare cause for a colonic ulcerated stricture. Gastroenterology 152:e5-e6

15. Chavapradit N, Angkasekwinai N (2018) Disseminated cryptococcosis in Crohn's disease: a case report. BMC Infect Dis 3:1-5

16. Medina Alvarez J, Tanta Chipana C, Arévalo Suarez F (2019) Proctocolitis by cryptococcus in an immunocompetent patient: first report in Peru. Rev Gastroenterol Peru 39:288-291

17. Praneenararat S (2014) Fungal infection of the colon. Clin Exp Gastroenterol 7:415-426

18. Perfect JR et al (2010) Clinical practice guidelines for the management of cryptococcal disease: 2010 update by the Infectious Diseases Society of America. Clin Infect Dis 50:291-322

Publisher's note Springer Nature remains neutral with regard to jurisdictional claims in published maps and institutional affiliations. 